\section{New Estonian records: Lichenized fungi}

\section{Polina Degtjarenko ${ }^{1,2}$, Inga Jüriado $^{1} \&$ Piret Lóhmus ${ }^{1}$}

${ }^{1}$ Department of Botany, Institute of Ecology and Earth Sciences, University of Tartu, Lai 40, 51005, Tartu, Estonia

E-mails: polina.degtjarenko@ut.ee,inga.juriado@ut.ee, piret.lohmus@ut.ee

${ }^{2}$ Biodiversity and Conservation Biology Research Unit, Swiss Federal Research Institute WSL, Zürcherstrasse 111, 8903, Birmensdorf, Switzerland

The lichenized fungi Cetrelia monachorum, Peltigera castanea and $P$. occidentalis are reported as new to Estonia after revision of herbarium samples; one further species, Peltigera frippi Holt.-Hartw., must be excluded from the list of Estonian lichens as a misidentification. $\mathrm{Ce}$ trelia specimens were investigated for lichen substances by thin layer chromatography (TLC; solvent A) (Orange et al., 2001), and the identity of $P$. occidentalis was confirmed using fungal ITS sequences. The abbreviations are used as follows: (1) for the country regions: NE - northeastern part, SE - southeastern part, SW - southwestern part; (2) for frequency classes (Freq.): rr - very rare, 1-2 localities, $r$ - rare, 3-5 localities, according to Randlane \& Saag (1999). Cited specimens are kept in the lichenological herbarium of the University of Tartu Natural History Museum and Botanic Garden (TU) and in the herbarium of the Tallinn Botanic Garden (TALL).

Cetrelia monachorum (Zahlbr.) W.L. Culb. \& C.F. Culb.

NE: Jõgeva Co., Puurmani comm., Alam Pedja Nature Reserve, in old swamp forest with black alders (Alnus glutinosa) in the tree layer $\left(58.5242^{\circ} \mathrm{N} 26.2683^{\circ} \mathrm{E}\right)$, on a fallen bark of Salix caprea; leg. P. Lõhmus 28 March 2003, det. P. Degtjarenko 7 July 2018, previously determined as C. olivetorum (Nyl.) W.L. Culb. \& C.F. Culb. (TU29049); - SE: Tartu Co., Kastre comm., Järvselja Nature Reserve, in old-growth forest $\left(58.2791^{\circ} \mathrm{N} 27.3239^{\circ} \mathrm{E}\right)$, on a fallen Fraxinus excelsior, leg. P. Lõhmus 18 July 2004, det. P. Degtjarenko 7 July 2018, previously determined as C. cetrarioides Delise W.L. Culb. \& C.F. Culb.
(TU26953); - SW: Pärnu Co., Häädemeeste comm., Nigula Nature Reserve, in old mixed forest with A. glutinosa, F. excelsior and Tilia cordata in the tree layer $\left(58.0460^{\circ} \mathrm{N} 24.7072^{\circ} \mathrm{E}\right)$, on S. caprea bark; leg. P. Lõhmus 24 April 2001, det. P. Degtjarenko 7 July 2018, previously determined as C. cetrarioides (TU17257). Freq.: r. - Until now, only two species, C. olivetorum and C. cetrarioides, were known in Estonia. Cetrelia monachorum is sorediate and morphologically similar to C. cetrarioides and C. olivetorum, but it contains imbricaric acid as the major medullary compound, and additionally perlatolic, 4-O-demethylimbricaric and anziaic acids in minor or trace amounts in the medulla (Figs. 1 and 2; Obermayer \& Mayrhofer, 2007; Kukwa $\&$ Motiejūnaitè, 2012). C. cetrarioides contains perlatolic acid as the major and imbricaric acid as minor medullary substance (Figs. 1 and 2; Kukwa \& Motiejūnaite, 2012). Furthermore, all Cetrelia species contain atranorin in the cortex. Spot test reactions of $C$. cetrarioides and $C$. monachorum are not sufficient to distinguish between the two species (e.g., Obermayer \& Mayrhofer, 2007; Kukwa \& Motiejūnaite, 2012), while TLC proved reliable to distinguish between these taxa. C. olivetorum could be distinguished from morphologically similar $C$. cetrarioides and C. monachorum by the strong sanguineous/red reaction with $\mathrm{C}$ which is caused by the presence of olivetoric acid in medulla (Figs. 1 and 2; Obermayer \& Mayrhofer, 2007; Golubkov et al., 2015). The new species to Estonia, C. monachorum, is recorded in other Baltic countries, Latvia (Moisejevs \& Degtjarenko, in prep.) and Lithuania (Kukwa \& Motiejūnaite, 2012), but also in more distant areas, such as Norway (Obermayer $\&$ Mayrhofer, 2007), Poland (Kukwa et al., 2012) and the European part of Russia (Tver Oblast) (Stepanchikova et al., 2011).

Peltigera castanea Goward, Goffinet \& Miadlikowska

NE: IdaVirumaa Co., Toila comm., upper edge of Päite clint, open alvar community $\left(59.4375^{\circ} \mathrm{N}\right.$, $27.053611^{\circ}$ ), on mosses, with Abietinella abietina (Hedw.) M. Fleisch., Bryum argentatum Hedw., Ceratodon purpureus (Hedw.) Brid. and Tortula ruralis (Hedw.) F. Weber \& D. Mohr. as associated bryophytes; leg. Leiti Kannukene (no. 32099) 6 Apr 2004, det. I. Jüriado 25 May 2018 (TALL L004908), previously determined as P. frippii (Suija et al., 2010). Freq.: rr. - Peltigera 


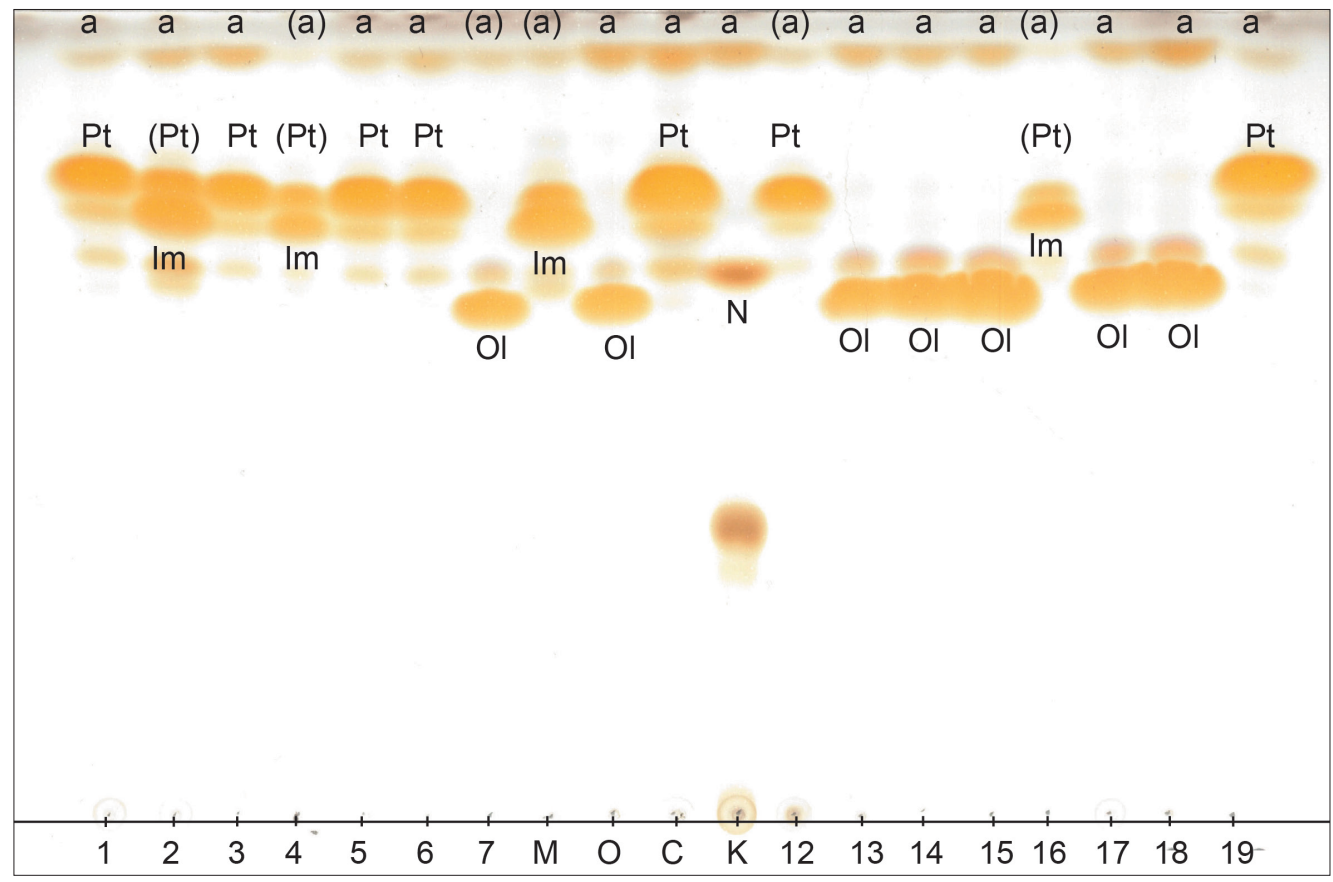

Fig. 1. Thin layer chromatography (TLC) plate of Cetrelia species in Estonia (after development with 10\% sulphuric acid): Cetrelia cetrarioides (tracks 1, 3, 5, 6, 12, 19), C. monachorum (tracks 2, 4, 16), C. olivetorum (tracks 7, 13, 14, 15, 17, 18); M, control of C. monachorum; O, control of C. olivetorum; C, control of C. cetrarioides; K, control of norstictic acid and atranorin. Spots of separated compounds: a, atranorin; Im, imbricaric acid; N, norstictic acid; Ol, olivetoric acid; Pt, perlatolic acid. Brackets point to minor amounts of compounds.

castanea was described quite recently from North America (Canada) and belongs to Peltigera didactyla complex (Goffinet et al., 2003). This taxon is confirmed to be a well-delimited species occurring also in Eurasia (Russia, Krasnoyarsk Territory) (Magain et al., 2018). Peltigera castanea thallus is foliose, small, to $6-8 \mathrm{~cm}$ across; lobes to $1.0-1.5 \mathrm{~cm}$ wide, with a smooth, shiny, chestnut brown, mostly non-tomentose upper cortex. The veins in underside of thallus are slightly darkening and rhizines are flocculent, often tufted and hedgerow forming (Goffinet et al., 2003). Marginal pycnidia and soredia are common, however, our specimen is esorediate (Fig. 3). Peltigera castanea occurs in (oro)boreal forests and alpine heaths, where it grows in open sites, on xerophytic moss mats (Goffinet et al., 2003). Also, in Estonia the species was found on xerophytic moss mats in open alvar grassland what is characteristic habitat for several rare terricolous lichens with arcto-alpine distribution (Leppik et al., 2015).

\section{Peltigera occidentalis (E. Dahl) Kristinsson}

SE: Valgamaa Co., Valga comm., Taheva forest district (comp. 3, subcomp. 22)., old swamp forest with black alder (Alnus glutinosa) and Norway spruce (Picea abies) in the tree layer $\left(57.70983^{\circ} \mathrm{N}, 26.214^{\circ} \mathrm{E}\right)$, on mosses, leg. I. Jüriado (no. 48) 14 July 1998, det. I. Jüriado 31 May 2018, previously determined as $P$. neopolydactyla (Gyeln.) Gyeln. (TU29725). Freq.: rr. - This species was tentatively recognized in Vitikainen (2007: 125), but is now confirmed to be well-delimited by molecular analyses (Magain et al., 2017). According to methods presented in Jüriado et al. (2017), the rDNA ITS sequence was obtained (I. Jüriado, No.637) from the herbarium specimen and on the basis of BLAST searches in the NCBI GenBank (http://blast.ncbi.nlm. nih.gov/Blast.cgi) the closest matches were with MG811764 and MG811762 (Peltigera occidentalis vouchers, $100 \%$ identity). Peltigera occidentalis differs from $P$. neopolydactyla by thicker, rigid and often emerald green thallus when wet 


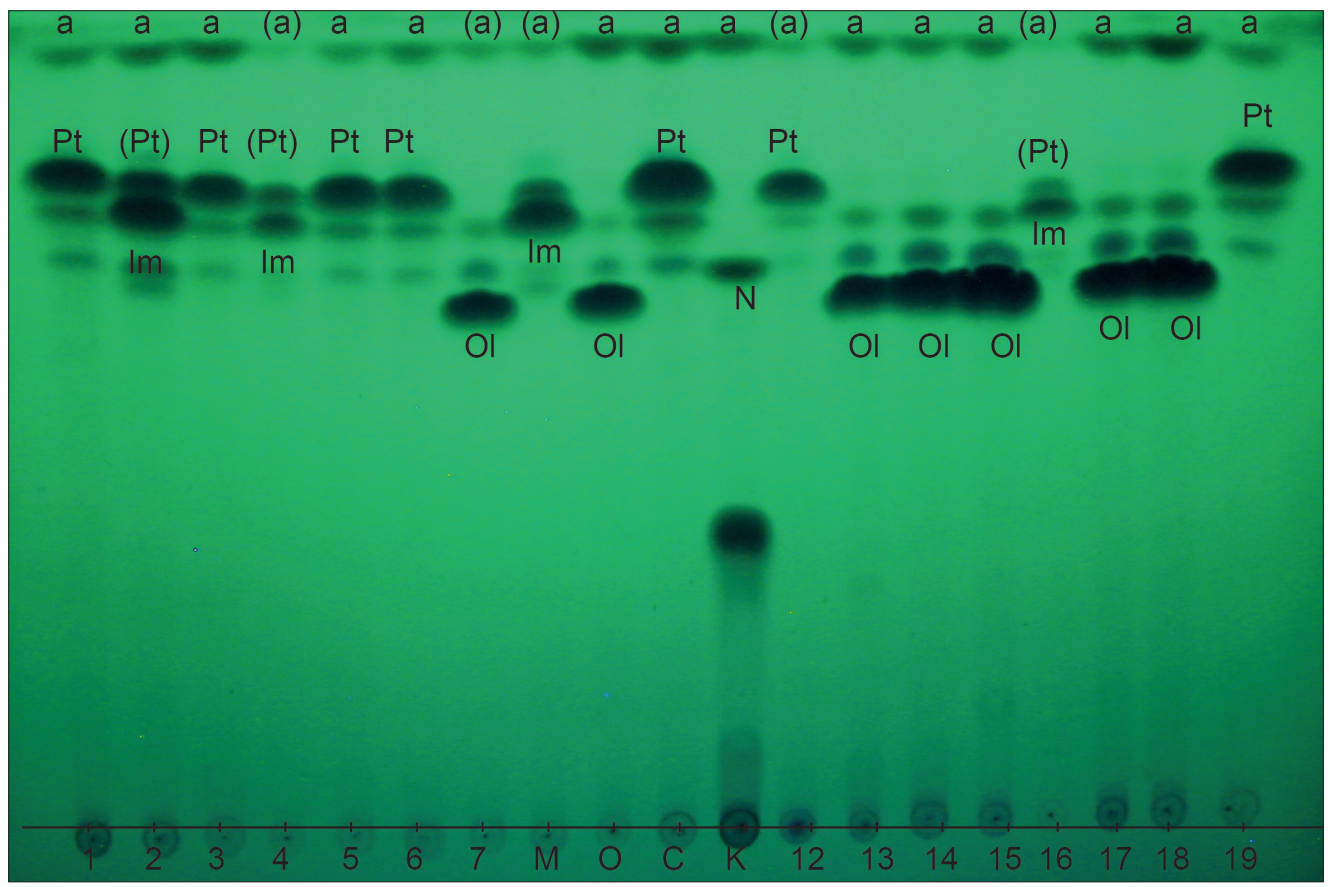

Fig. 2. Thin layer chromatography (TLC) plate of Cetrelia species in Estonia (after running, photographed under UV-light, $254 \mathrm{~nm}$ ): Cetrelia cetrarioides (tracks 1, 3, 5, 6, 12, 19), C. monachorum (tracks 2, 4, 16), C. olivetorum (tracks 7, 13, 14, 15, 17, 18). See Figure 1 for abbreviations of compounds.

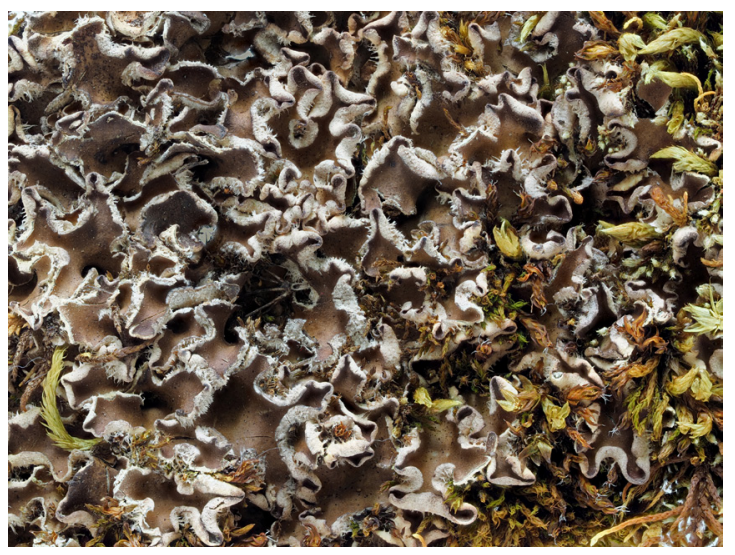

Fig. 3. Peltigera castanea (TALL L004908). Photo Andres Saag.

(Vitikainen, 2007). In underside of thallus the veins are brown to black in the center, rhizines are tufted, branched, and usually not over 5 $\mathrm{mm}$ long. Peltigera neopolydactyla has usually paler veins, rhizines are slender, little branched, and often over $7 \mathrm{~mm}$ long. Peltigera occidentalis is widespread in oligotrophic and mesic forests in boreal zone and in subalpine heaths and meadows (Vitikainen, 2007).

\section{ACKNOWLEDGMENTS}

This work was supported by the Estonian Research Council (grants PUT1017, IUT20-30 and IUT34-7) and by Mobilitas Pluss programme (MOBTP66, supported also by European Regional Development Fund). Rolands Moisejevs (University of Daugavpils, Latvia) is thanked for providing the idea to check the herbarium specimens of Cetrelia and for help with preparing figures and manuscript. Rasmus Puusepp (University of Tartu) is acknowledged for assistance in molecular lab. Andres Saag (University of Tartu) is thanked for the photo of Peltigera castanea.

\section{REFERENCES}

Goffinet, B., Miadlikowska, J. \& Goward, T. 2003. Phylogenetic inferences based on nrDNA sequences 
support five morphospecies within the Peltigera didactyla complex (lichenized Ascomycota). Bryol ogist 106: 349-364. https://doi.org/10.1639/01

Golubkov, V., Matwiejuk, A., Bely, P. \& Tsurykau, A. 2015. Revision of the genus Cetrelia (Lecanorales, Ascomycota) in the Białowieża Forest (Belarussian part). Steciana 19: 123-132. https://doi. org/10.12657/steciana.019.014

Jüriado, I., Kaasalainen, U. \& Rikkinen, J. 2017. Specialist taxa restricted to threatened habitats contribute significantly to the regional diversity of Peltigera (Lecanoromycetes, Ascomycota) in Estonia. Fungal Ecology 30: 76-87. https://doi. org/10.1016/j.funeco.2017.08.004

Kukwa, M. \& Motiejūnaitè, J. 2012. Revision of the lichen genera Cetrelia and Punctelia (Lecanorales, Ascomycota) in Lithuania with implications for their conservation. Herzogia 25: 5-14. https:// doi.org/10.13158/heia.25.1.2010.5

Kukwa, M., Pietnoczko, M. \& Czyzewska, K. 2012. The lichen family Parmeliaceae in Poland II. The genus Cetrelia. Acta Societatis Botanicorum Poloniae 81: 43-52.

Leppik, E., Jüriado, I., Suija, A. \& Liira, J. 2015. Functional ecology of rare and common epigeic lichens in alvar grasslands. Fungal Ecology 13: 66-76. https://doi.org/10.1016/j.funeco.2014.08.003

Magain, N., Miadlikowska, J., Goffinet, B., Sérusiaux, E. \& Lutzoni, F. 2017. Macroevolution of specificity in cyanolichens of the genus Peltigera section polydactylon (Lecanoromycetes, Ascomycota). Systematic Biology 66: 74-99.
Magain, N., Truong, C., Goward, T., Niu, D., Goffinet, B., Sérusiaux, E., Vitikainen, O., Lutzoni, F. \& Miadlikowska, J. 2018. Species delimitation at a global scale reveals high species richness with complex biogeography and patterns of symbiont association in Peltigera section Peltigera (1ichenized Ascomycota: Lecanoromycetes). Taxon 13 September 2018: 35 pp.

Obermayer, W. \& Mayrhofer, H. 2007. Hunting for Cetrelia chicitae (lichenized Ascomycetes) in the eastern European Alps (including an attempt for a morphological characterization of all taxa of the genus Cetrelia in Central Europe). Phyton 47: 231-290.

Orange, A., James, P. W. \& White, F. J. 2001. Microchemical methods for the identification of lichens. British Lichen Society, London.

Randlane, T. \& Saag, A. (eds). 1999. Second checklist of lichenized, lichenicolous and allied fungi of Estonia. Folia Cryptogamica Estonica 35: 1-132.

Stepanchikova, I. S., Kukwa, M., Notov, A. A. \& Himelbrant, D. E. 2011. Novye dannye o lixenoflore Tverskoj oblasti. Vestnik TvGU, Biologija i ekologija 23: 137-142 (In Russian).

Suija, A., Piin-Aaspõllu, T., Ahti, T., Marmor, L., Jüriado, I., Kannukene, L. \& Lõhmus, P. 2010. New Estonian records: Lichenized and lichenicolous fungi. Folia Cryptogamica Estonica 47: 105-107.

Vitikainen, O. 2007. Peltigeraceae. Nordic Lichen Flora 3: $113-129$. 